\title{
Effect of Organic Manure and Zinc Fertilization on Zinc Transformation and Biofortification of Crops in Vertisols of Central India
}

\author{
Shahina Tabassum ${ }^{1}$, Sabha Jeet ${ }^{2}$, Ratan $\mathrm{Kumar}^{3}$, C. M. Dev ${ }^{4}$, Pramod Kumar $^{5} \&$ Rehana $^{6}$ \\ ${ }^{1}$ National Centre of Organic Farming, Ghaziabad, India \\ ${ }^{2}$ Krishi Vigyan Kendra Halsi, Bihar Agricultural University, Lakhisarai, Sabour, Bhagalpur, India \\ ${ }^{3}$ K. V. K. Rohtas, Bihar Agricultural University, Bihar, Sabour, India \\ ${ }^{4}$ C. O. A. Korea, I. G. K. V. V. Raipur, C. G., India \\ ${ }^{5}$ K. V. K., West Singhbhum, Bihar Agricultural University, Ranchi, Jharkhand, India \\ ${ }^{6}$ F. E. O., J. N. K. V. V. Jabalpur, India
}

Correspondence: Shahina Tabassum, National Centre of Organic Farming, Ghaziabad-201002 U.P., India. Tel: 91-947-298-2552. E-mail: agrisabhaj@gmail.com

Received: April 15, 2014 Accepted: June 10, 2014 Online Published: July 15, 2014

doi:10.5539/jas.v6n8p221 URL: http://dx.doi.org/10.5539/jas.v6n8p221

\begin{abstract}
The studies are described to indicate biofortification of micronutrients into seed and their various fractions availability into soil. The primary application of biofortification is to alleviate micronutrient deficiencies in developing country populations. Soil samples were analyzed for the DTPA (pH 7.3), extractable micronutrients were extracted by $0.005 \mathrm{M}$ DTPA, $0.01 \mathrm{M} \mathrm{CaCl}_{2}$ and $0.1 \mathrm{M}$ triethanol amine and determined on atomic absorption spectrophotometer (AAS). The total zinc was determined with hydrofluoric and perchloric acid by AAS. The objectives of experiment were to examine the effect of $\mathrm{Zn}$ biofortification and transformation under various organic and zinc fertilization for realizing maximum use efficiency in Vertisols. Among organic manures, sugarcane press mud recorded more yield, higher $\mathrm{Zn}$ concentration, fractions, uptake and their use efficiency than other. Application of Zinc @ $10 \mathrm{~kg} \mathrm{ha}^{-1}$ recorded the highest water soluble Zn, exchangeable Zn, complexed $\mathrm{Zn}$, organic bond zinc, occluded $\mathrm{Zn}$ and residual zinc in rice and chickpea, respectively. Various fractions of zinc positively correlated with each other. However, Organic and zinc fertilization in rice offers a practical and useful approach to improve bioavailable $\mathrm{Zn}$ in rice and chickpea.
\end{abstract}

Keywords: biofortification, chickpea, rice transformation, vertisols, zinc

\section{Introduction}

Micronutrients play a vital role in plant nutrition; their importance has attracted the attention of agriculture scientists all over the world. Application of Zn fertilizers or Zn-enriched NPK fertilizers (e.g., agronomic biofortification) offers a rapid solution to the problem, and represents useful complementary approach to on-going breeding programs. There is increasing evidence showing that foliar or combined soil + foliar application of $\mathrm{Zn}$ fertilizers under field conditions are highly effective and very practical way to maximize uptake and accumulation of $\mathrm{Zn}$ in whole grain. Zinc-enriched grains are also of great importance for crop productivity resulting in better seedling vigor, denser stands and higher stress tolerance on potentially Zn-deficient soils. Agronomic biofortification strategy appears to be essential in keeping sufficient amount of available $\mathrm{Zn}$ in soil solution and maintaining adequate $\mathrm{Zn}$ transport to the seeds during reproductive growth stage. Finally, agronomic biofortification is required for optimizing and ensuring the success of genetic biofortification of cereal grains with $\mathrm{Zn}$. In case of greater bioavailability of the grain $\mathrm{Zn}$ derived from foliar applications than from soil, agronomic biofortification would be a very attractive and useful strategy in solving $\mathrm{Zn}$ deficiency-related health problems globally and effectively.

Zinc $(\mathrm{Zn})$ is one of the eight trace elements among $\mathrm{Fe}, \mathrm{Cu}, \mathrm{Mn}, \mathrm{Cl}, \mathrm{B}$, Mo and Ni which are essential for the normal healthy growth and reproduction of crop plants. It plays a key role in various plant metabolism processes such as the development of cell wall, respiration, carbohydrate metabolism and gene regulation (Cakmak, 2008). 
Zinc deficiencies also results in the inability of rice plant to support root respiration during flooded conditions (Slaton et al., 2005). Zinc is a component of the enzyme system that leads to the formation of indole acetic acid from tryptophane which is found in plants and also in the activity of dehydropeptidase and glycoglycine dipeptidase, which play a specific role in the protein metabolism. It is required for the formation of certain microbial enzymes. Under deficient condition, the crops are likely to respond to the application of zinc, as the same is the constituent of various enzymes and involved in photosynthesis and nitrogen metabolism of plants: It also regulates the auxin content in plants; hence, the plant growth and maturity are adversely affected due to its deficiency. Rice and most staple cereals contain low zinc (Zn) levels, most of which is lost during grain processing. Populations with monotonous diets consisting mainly of cereals are especially prone to Zn deficiency, which affects about two billion people (Sperotto et al., 2012). Supplementation or food fortification programs have not always been successful. Breeding and genetical programme is also not so successful on farmer's field. Crop $\mathrm{Zn}$ fertilization is an alternative solution that efficiently mobilize, enhance their uptake by different edible portions of plant also not very effective due to $\mathrm{Fe}$ soil insolubility. Organic manures play a vital role in improving availability of zinc by direct contribution as well as indirectly by influencing chemical transformation reaction and microbial activity (Rathod et al., 2012). Zinc exists in soil in different forms viz., primary and secondary minerals; insoluble inorganic and organic precipitates; soluble organic complexes; exchangeable and adsorbed forms; and soil solution zinc. These forms are in a state of dynamic equilibrium. The amount and rate of transformation of these forms determine the size of the labile zinc pool (Mishra et al., 2009). The deficiency of micronutrients has become a major constraint of productivity, stability and sustainability in many Indian soils. Deficiency of micronutrients may either be primary, due to their low total contents or secondary, caused by soil factors reducing their availability to plants. The emergence of micronutrient deficiency has generally been considered as secondary (Sharma \& Choudhary, 2007). If zinc deficiency is not diagnosed and rectified timely, the problem will become alarming in the years to come because land has been cultivated more intensively to have additional production to meet the requirement of increasing population. Till date very meager information is available on different forms of zinc and their availability in rice-chickpea cropping sequence in Vertisols of black soils. In this paper, we have attempted to examine the effect of organic manures and $\mathrm{Zn}$ on sustaining productivity, $\mathrm{Zn}$ biofortification and their transformation in rice-chickpea cropping sequence for realizing sustainable production.

\section{Material and Methods}

A field experiment was conducted at Jabalpur during kharif 2008-2009 and rabi 2009-2010 sixteen treatments comprised under split plot design with replicated thrice. In which four source of organic manures (No manures, $5 \mathrm{t} \mathrm{ha} \mathrm{a}^{-1}$ farm yard manure, $5 \mathrm{t} \mathrm{ha}^{-1}$ poultry manure and $5 \mathrm{t} \mathrm{ha}^{-1}$ sugarcane press mud) as main plot treatments and four doses of zinc $\left(0,2.5,5.0\right.$ and $\left.10.0 \mathrm{~kg} \mathrm{Zn} \mathrm{ha}^{-1}\right)$ applied with term of $\mathrm{ZnSO}_{4} \cdot 7 \mathrm{H}_{2} \mathrm{O}$ as sub plot treatments. The soil of the experimental site falls under Vertisols and belongs to Kheri -series of fine montmorillonite -Hyperthermic family of Typic Haplusterts popularly known as "Black soil". The soil of experimental site was clayey in texture, neutral in reaction, non calcareous, medium in organic carbon content and low in DTPA extractable $\mathrm{Zn}$. The Micro nutrients in organic manures and physico-chemical properties of soil are presented vide Table 1 and Table 2. The rice (JR-201) and chickpea (JG-11) were sown in July 2009 and December 2009, respectively. A basal dose of 60:80:40 and 20:60:20 N, $\mathrm{P}_{2} \mathrm{O}_{5}$, and $\mathrm{K}_{2} \mathrm{O}$ were applied before sowing of rice and chickpea, respectively through urea, super phosphate and muriate of potash fertilizers. The $60 \mathrm{~kg} \mathrm{~N}$ was applied rice crop in two splits doses during crop growth.

Table 1. Micro nutrients in organic manures

\begin{tabular}{lllll}
\hline \multirow{2}{*}{ Organic manures } & \multicolumn{4}{l}{ Micro nutrients $\left(\mathrm{mg} \mathrm{kg}^{-1}\right)$} \\
\cline { 2 - 5 } & $\mathrm{Zn}$ & $\mathrm{Cu}$ & $\mathrm{Fe}$ & $\mathrm{Mn}$ \\
\hline Farm yard manure & 93.75 & 37 & 2599.6 & 224 \\
Poultry manure & 212.7 & 40 & 2419.8 & 368 \\
Sugarcane press mud & 239.7 & 81 & 2046.9 & 454 \\
\hline
\end{tabular}


Table 2. Physico-chemical properties of soil

\begin{tabular}{ll}
\hline Properties & Content \\
\hline Sand & $25.3 \%$ \\
Silt & $17.9 \%$ \\
Clay & $56.8 \%$ \\
Soil texture & Clayey \\
Soil pH (1:2) & 7.6 \\
Electrical conductivity & $0.22 \mathrm{dS} \mathrm{m}^{-1} 25^{\circ} \mathrm{C}$ \\
Calcium carbonate & $20.5 \mathrm{~g} \mathrm{~kg}^{-1}$ \\
Organic carbon & $4.5 \mathrm{~g} \mathrm{~kg}^{-1}$ \\
Available Nitrogen & $223.0 \mathrm{~kg} \mathrm{ha}^{-1}$ \\
Available Phosphorus (Olsen) & $25.9 \mathrm{~kg} \mathrm{ha}^{-1}$ \\
Available Potassium & $314.3 \mathrm{~kg} \mathrm{ha}^{-1}$ \\
Available Sulphur & $18.7 \mathrm{mg} \mathrm{kg}^{-1}$ \\
DTPA extractable Zn & $0.70 \mathrm{mg} \mathrm{kg}^{-1}$ \\
DTPA extractable Cu & $1.40 \mathrm{mg} \mathrm{kg}^{-1}$ \\
DTPA extractable Fe & $9.30 \mathrm{mg} \mathrm{kg}^{-1}$ \\
DTPA extractable Mn & $5.48 \mathrm{mg} \mathrm{kg}^{-1}$ \\
\hline
\end{tabular}

Composite representative soil samples were collected from each plot thereafter soil samples were air dried, processed by wooden pestle- mortar then passed through $2 \mathrm{~mm}$ sieve and finally prepared samples were used for analysis. Processed soil samples $(<2 \mathrm{~mm})$ were analyzed for different physicochemical properties following standard procedures i.e. Soil $\mathrm{pH}$ was determined by glass electrode method in 1:2 soil: water suspension (Jackson, 1965). Electrical conductivity was measured in the supernatant liquid of 1:2 soil: water suspensions by solu-bridge method (Jackson, 1965). Organic carbon was determined by rapid titration method of Walkley and Black as described by Jackson (1965). Calcium carbonate in soil samples was determined by the rapid titration method as described by Jackson (1965). Available nitrogen in soil samples was determined by adopting the alkaline permanganate method (Subbiah \& Asija, 1956). The phosphorus content of soil was estimated by colourimetric procedure described by Olsen et al. (1954). The available potassium was extracted by neutral normal ammonium acetate and estimated by using Flame Photometer (Muhr et al., 1963). Available sulphur was determined by $0.15 \%$ solution of calcium chloride turbidimetric method (Chesin \& Yien, 1951). Soil samples were also analyzed for the DTPA (Diethylene Triamine Penta Acetic acid pH 7.3), extractable micronutrients were extracted by $0.005 \mathrm{M}$ DTPA, $0.01 \mathrm{M} \mathrm{CaCl}_{2}$ and $0.1 \mathrm{M}$ triethanol amine (TEA) and determined on atomic absorption spectrophotometer (Lindsay \& Norvell, 1978). The total zinc was determined, after digesting soil with hydrofluoric (HF) and perchloric acid $\left(\mathrm{HClO}_{4}\right)$ as described by Jackson (1965) on atomic absorption spectrophotometer. Various fractions of zinc were determined by procedure of Smith and Shoukry (1968) with some modification as suggested by Iyenger and Deb (1977). The extraction procedure is given in the flow sheet Figure 1. The extraction period of one hour was employed and suspension was centrifuged to get clear solution and determined for zinc on atomic absorption spectrophotometer. The residual zinc was determined by subtracting all fractions of zinc from total zinc content in soil. Multiple correlations of different $\mathrm{Zn}$ fractions were worked out by standard statistical methods. Zinc use efficiency was calculated as per formula used by Dobermann (2005). The zinc use efficiency was calculated by using the following formula: Zinc utilization (\%) $=\{$ Zinc uptake in treated plot - Zinc uptake in control plot/Zinc dose $\} \times 100$. 


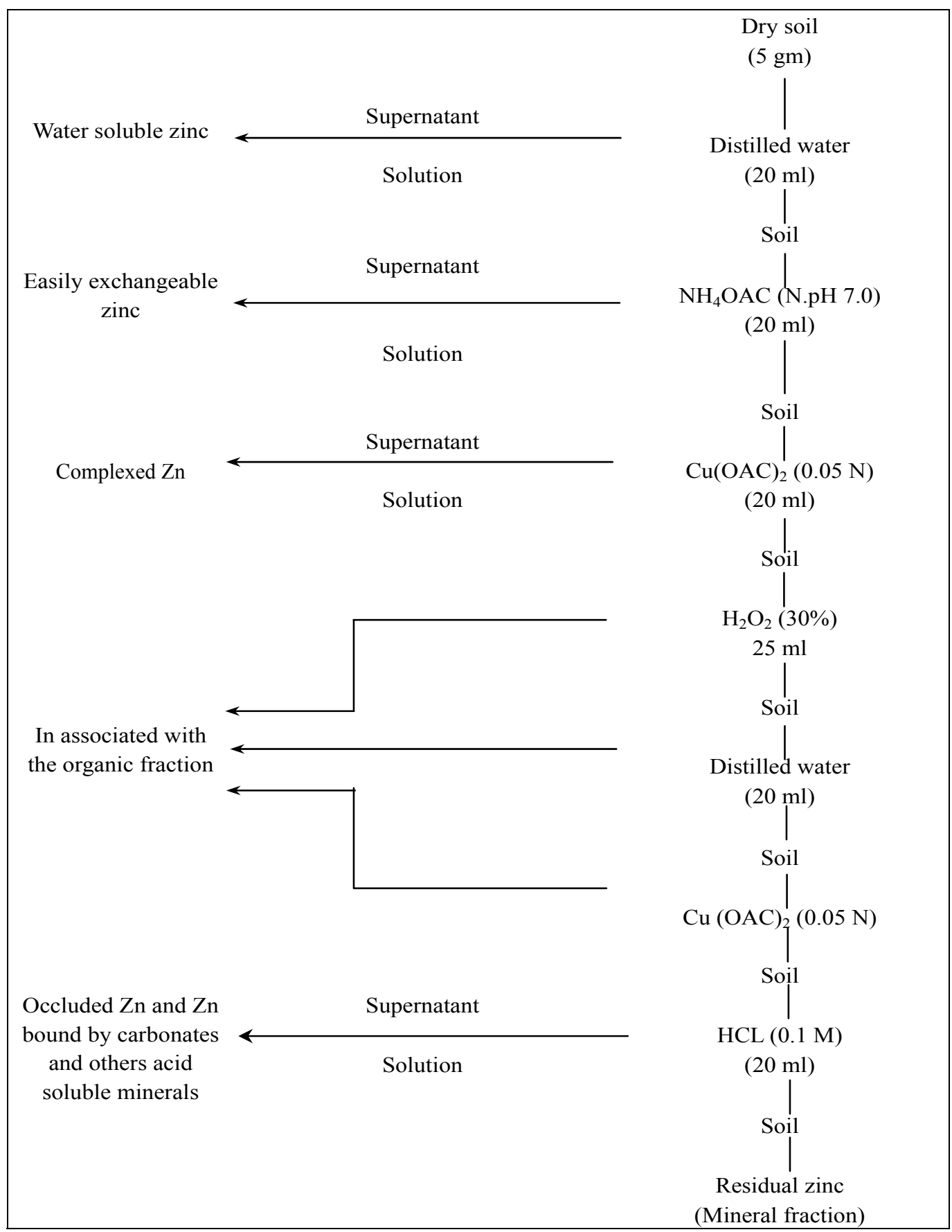

Figure 1. Flow sheet showing extraction mode to determine various soil fractions of zinc in soil

\section{Results and Discussion}

\subsection{Zinc Concentration}

Application of organic manures in the form of FYM, poultry manure and sugarcane press mud significantly increased the zinc concentration in rice and chickpea. The percent response was in the order of sugarcane press mud $(16.57 \%)>$ poultry manure $(13.04 \%)>$ farm yard manure $(10.38 \%)$ in grain, sugarcane press mud $(12.50 \%)>$ poultry manure $(12.22 \%)>$ farm yard manure $(7.81 \%)$ in straw, sugarcane press mud $(30.43 \%)>$ poultry manure $(23.83 \%)>$ farm yard manure $(14.71 \%)$ in dehusk and sugarcane press mud $(17.53 \%)>$ poultry manure $(15.44 \%)>$ farm yard manure $(11.02 \%)$ in husk of rice. The residual effect of organic manures significantly increased the $\mathrm{Zn}$ concentration in grain and stover of 
chickpea over control. The percent response was $(8.81 \%)>(6.02 \%)>(3.46 \%)$ in grain and $(27.9 \%)>$ $(16.4 \%)>(7.3 \%)$ in stover, of the order of performance was sugarcane press mud $>$ farm yard manure $>$ poultry manure. In contrast to foliar $\mathrm{Zn}$ fertilization significantly $(\mathrm{P}<0.05)$ increased the $\mathrm{Zn}$ concentration in rice grain and husk and grain and stover of chickpea (Table 3), consisted with the previous studies (Wu et al. 2010; Fang et al. 2010). The zinc concentration increased by $15.9 \%, 33.3 \%, 53.7 \%$ in grain, $18.1 \%$, $26.4 \%, 34.5 \%$ in straw, $18.6 \%, 31.7 \%, 44.7 \%$ in dehusk and by $14.5 \%, 22.8 \%$ and $25.0 \%$ in husk with application of $2.5 \mathrm{~kg} \mathrm{Zn} \mathrm{ha}{ }^{-1}, 5 \mathrm{~kg} \mathrm{Zn} \mathrm{ha-1}$, and $10 \mathrm{~kg} \mathrm{Zn} \mathrm{ha}^{-1}$ respectively. Similarly, zinc concentration of chickpea increased by $10.5 \%, 15.3 \%, 19.8 \%$ in grain and $15.2 \%, 23.4 \%, 32.9 \%$ in straw, as a residual effect of $2.5 \mathrm{~kg} \mathrm{Zn} \mathrm{ha}^{-1}, 5 \mathrm{~kg} \mathrm{Zn} \mathrm{ha}^{-1}, 10 \mathrm{~kg} \mathrm{Zn} \mathrm{ha}^{-1}$, respectively. Thus, application of $\mathrm{Zn}$ as an effective method could boost $\mathrm{Zn}$ level in rice grain and subsequent crops. Here, in this study, particular attention should be given in the $\mathrm{Zn}$ concentration of grain and dehusk rice, as this is the predominant fraction consumed by human. Increase in the concentration of micro nutrients due to application of farm yard manure and other organic manures have been reported by Kumar et al. (2004). These results are also in agreement with the findings of Akinrinde et al. (2006).

Table 3. Effect of organic manures and $\mathrm{Zn}$ fertilization on Zinc concentration, DTPA extractable Zn by rice- chickpea cropping sequence

\begin{tabular}{|c|c|c|c|c|c|c|c|c|}
\hline \multirow{3}{*}{ Treatments } & \multicolumn{6}{|c|}{ Zinc Concentration $\left(\mathrm{mg} \mathrm{kg}^{-1}\right)$} & \multicolumn{2}{|c|}{ DTPA extractable- $\mathrm{Zn}\left(\mathrm{mg} \mathrm{kg}^{-1}\right)$} \\
\hline & \multicolumn{4}{|c|}{ Rice } & \multicolumn{2}{|c|}{ Chickpea } & \multirow{2}{*}{ Rice } & \multirow{2}{*}{ Chickpea } \\
\hline & Grain & straw & Dehusk- rice & Husk & Grain & Straw & & \\
\hline \multicolumn{9}{|c|}{ Organic Manures } \\
\hline Control & 14.9 & 18.2 & 10.0 & 35.6 & 37.4 & 13.8 & 1.07 & 1.14 \\
\hline FYM & 16.4 & 19.6 & 11.4 & 39.5 & 39.6 & 16.0 & 1.19 & 1.29 \\
\hline PM & 16.8 & 20.4 & 12.3 & 41.1 & 38.7 & 14.8 & 1.24 & 1.33 \\
\hline SPM & 17.3 & 20.4 & 13.0 & 41.8 & 40.7 & 17.6 & 1.29 & 1.38 \\
\hline $\mathrm{CD}(\mathrm{P}=0.05)$ & 1.07 & 1.05 & 1.03 & 1.96 & 1.83 & 1.19 & 0.10 & 0.10 \\
\hline \multicolumn{9}{|c|}{ Zinc Fertilization } \\
\hline $\mathrm{Zn}_{0}$ & 13.0 & 16.4 & 9.4 & 34.3 & 35.1 & 13.2 & 0.87 & 0.96 \\
\hline $\mathrm{Zn}_{1}$ & 15.1 & 19.4 & 11.2 & 39.2 & 38.8 & 15.2 & 1.11 & 1.27 \\
\hline $\mathrm{Zn}_{2}$ & 17.3 & 20.7 & 12.4 & 41.5 & 40.5 & 16.3 & 1.31 & 1.40 \\
\hline $\mathrm{Zn}_{3}$ & 20.0 & 22.0 & 13.7 & 42.9 & 42.0 & 17.5 & 1.50 & 1.52 \\
\hline $\mathrm{CD}(\mathrm{P}=0.05)$ & 1.04 & 1.02 & 0.83 & 2.71 & 1.98 & 0.84 & 0.08 & 0.09 \\
\hline
\end{tabular}

\subsection{DTPA Extractable - Zn}

The result on the DTPA extractable zinc was presented in Table 3. As regards the effect of application of various organic manures, increase in zinc content of soil over control. The DTPA extractable $\mathrm{Zn}$ (Table 3) in the soil of the current field study was higher than the critical level for rice $\left(0.8 \mathrm{mg} \mathrm{kg}^{-1}\right)$; Dobermann and Fairhurst (2000), thus the plant was in the sufficient $\mathrm{Zn}$ nutritional status. Our results are also agreement with Appauv et al. (2001) they have observed that the incorporation of organic manures (poultry manure, goat manure and farm yard manure) increased the available zinc content. The zinc content in soil of rice and chickpea increased with the increasing level of zinc from 28.6 to $73.3 \%$ and $32.8 \%$ to $58.4 \%$. We observed that $\mathrm{Zn}$ content increased in plant parts by the combined application of poultry manure and $\mathrm{ZnSO}_{4}$. These results are in conformity with the work of Patnaik et al. (2008) who observed the significant increase in DTPA extractable zinc content $0.58,1.26,2.73,4.16$ and $5.78 \mathrm{mg} \mathrm{kg}^{-1}$ at 0,25 , 50,75 and $100 \mathrm{Kg} \mathrm{ZnSO} \mathrm{ha}^{-1}$ applications. Similar findings have been reported by Meena et al. (2006).

\subsection{Fractionation of Zinc}

Effect of organic manures and zinc found to be also significant after harvest of rice (Table 4). Various fractions 
increased in the order of $13.4 \%>12.7 \%>8.1 \%, 24.0 \%>15.9 \%>8.2 \%, 19.2 \%>10.8 \%>10.7 \%$ and $15.3 \%>$ $12.4 \%>11.6 \%$ with the application sugarcane press mud $>$ poultry manure $>$ farm yard manure in case of water soluble, exchangeable, complexed and organically bound fractions, respectively. Similarly, the $\mathrm{Zn}$ content in water soluble, exchangeable, complexed and organically bound fractions increased with the increasing levels of zinc, the maximum value obtained $66.7 \%, 24.5 \%, 75.4 \%$ and $19.8 \%$, respectively, at the level of $10 \mathrm{~kg} \mathrm{Zn} \mathrm{ha}^{-1}$, over control. However, the occluded and residual fractions of zinc were found to be not significant due to the application of either organic manures or zinc.

Table 4. Effect of organic manures and $\mathrm{Zn}$ on various fractions $\left(\mathrm{mg} \mathrm{kg}^{-1}\right)$ of zinc in soil after harvest of rice and chickpea (mean of two years)

\begin{tabular}{|c|c|c|c|c|c|c|c|c|c|c|c|c|}
\hline \multirow{2}{*}{ Treatments } & \multicolumn{2}{|c|}{$\begin{array}{l}\text { Water soluble } \\
\text { zinc }\end{array}$} & \multicolumn{2}{|c|}{ Exchangeable Zn } & \multicolumn{2}{|c|}{ Complexed Zn } & \multicolumn{2}{|c|}{ Organic bound $\mathrm{Zn}$} & \multicolumn{2}{|c|}{ Occluded Zn } & \multicolumn{2}{|c|}{ Residual Zn } \\
\hline & Rice & Chickpea & Rice & Chickpea & Rice & Chickpea & Rice & Chickpea & Rice & Chickpea & Rice & Chickpea \\
\hline \multicolumn{13}{|c|}{ Organic Manures } \\
\hline Control & 0.062 & 0.061 & 0.17 & 0.16 & 0.69 & 0.67 & 0.69 & 0.66 & 1.08 & 1.06 & 70.72 & 68.7 \\
\hline FYM & 0.067 & 0.065 & 0.19 & 0.18 & 0.76 & 0.74 & 0.77 & 0.76 & 1.10 & 1.08 & 71.56 & 69.2 \\
\hline PM & 0.070 & 0.067 & 0.20 & 0.18 & 0.76 & 0.75 & 0.78 & 0.76 & 1.11 & 1.08 & 72.07 & 70.1 \\
\hline SPM & 0.073 & 0.072 & 0.22 & 0.19 & 0.82 & 0.81 & 0.80 & 0.77 & 1.18 & 1.17 & 72.67 & 71.6 \\
\hline $\begin{array}{c}\mathrm{CD} \\
(\mathrm{P}=0.05)\end{array}$ & 0.003 & 0.003 & 0.008 & 0.009 & 0.051 & 0.037 & 0.033 & 0.050 & NS & 0.069 & NS & NS \\
\hline \multicolumn{13}{|c|}{ Zinc Fertilization } \\
\hline $\mathrm{Zn}_{0}$ & 0.051 & 0.051 & 0.17 & 0.16 & 0.56 & 0.54 & 0.69 & 0.69 & 1.07 & 1.05 & 70.24 & 68.2 \\
\hline $\mathrm{Zn}_{1}$ & 0.060 & 0.059 & 0.19 & 0.18 & 0.68 & 0.67 & 0.74 & 0.72 & 1.09 & 1.08 & 71.37 & 69.2 \\
\hline $\mathrm{Zn}_{2}$ & 0.075 & 0.072 & 0.20 & 0.19 & 0.80 & 0.79 & 0.79 & 0.75 & 1.14 & 1.11 & 72.26 & 70.5 \\
\hline $\mathrm{Zn}_{3}$ & 0.085 & 0.083 & 0.21 & 0.19 & 0.99 & 0.96 & 0.82 & 0.77 & 1.17 & 1.15 & 73.16 & 71.7 \\
\hline $\begin{array}{c}C D \\
(\mathrm{P}=0.05)\end{array}$ & 0.004 & 0.004 & 0.008 & 0.010 & 0.036 & 0.037 & 0.044 & 0.043 & NS & NS & NS & NS \\
\hline
\end{tabular}

Residual effect of organic manures and zinc had also significant on various forms of zinc after harvest of chickpea (Table 4). Various fractions increased in the order of $19.5 \%>11.0 \%>6.9 \%, 17.6 \%>12.8 \%>9.2 \%$, $21.0 \%>12.8 \%>10.3 \%$ and $16.5 \%>14.5 \%>14.4 \%$ with the residual effect of sugarcane press mud $>$ poultry manure $>$ farm yard manure in case of water soluble, exchangeable, complexed and organically bound fractions, respectively. Similarly, the $\mathrm{Zn}$ content in water soluble, exchangeable, complexed and organically bound fractions increased with the increasing levels of zinc, maximum value was reported as $64.6 \%, 23.0 \%, 78.1 \%$ and $11.9 \%$, respectively, at the level of $10 \mathrm{~kg} \mathrm{Zn} \mathrm{ha}^{-1}$, over control. However, the occluded and residual fractions of zinc were not affected significantly due to the application of either organic manures or zinc. Our finding have been supported by Jalali et al. (1999) who studied the distribution of zinc in various chemical pools in 104 soil samples. Water soluble and exchangeable $\mathrm{Zn}$ levels were low. Complexed/Chelated zinc content varied from 0.32 to $3.22 \mathrm{ppm}$. Shetty et al. (2001) also studied the distribution of $\mathrm{Zn}$ among different fractions. They also reported that water soluble + exchangeable forms vary in the range of 0.14- $0.32 \mathrm{mg} \mathrm{kg}^{-1}$ with the lowest contribution (0.32-0.74 percent) to total $\mathrm{Zn}$. However, residual fraction contributed highest to total zinc (86.68- 91.64 per cent). Rupa et al. (2003) found that the application of $7.5 \mathrm{mg} \mathrm{Zn} \mathrm{kg} \mathrm{m}^{-1}$ soil showed the maximum fractions of soil $\mathrm{Zn}$ and significantly increased the $\mathrm{Zn}$ utilization by wheat $(0.87-1.17 \%)$ as compared to other $\mathrm{Zn}$ levels $(0.58-0.88 \%)$.

\subsection{Zinc Uptake}

The uptake of nutrient is a function of yield and its concentration in crop. The application of $\mathrm{Zn}$ increases in the yield as well as zinc concentration, ultimately the $\mathrm{Zn}$ uptake also increased. Application of organic manures, zinc uptake increased from 61.1 to $87.4 \mathrm{~g} \mathrm{ha}^{-1}$ rice grain, 83.7 to $119.8 \mathrm{~g} \mathrm{ha}^{-1}$ rice straw, 65.5 to $89.8 \mathrm{~g} \mathrm{ha}^{-1} \mathrm{~g} \mathrm{ha}^{-1}$ chickpea grain and 38.3 to $59.6 \mathrm{~g} \mathrm{ha}^{-1}$ chickpea stover over control to sugarcane press mud. Similarly, Zinc 
uptake increased 51.2 to $102.1 \mathrm{~g} \mathrm{ha}^{-1}$ in rice grain, 70.0 to $134.2 \mathrm{~g} \mathrm{ha}^{-1}$ in rice straw, 56.7 to $94.6 \mathrm{~g} \mathrm{ha}^{-1}$ in chickpea grain and 33.7 to $63.1 \mathrm{~g} \mathrm{ha}^{-1}$ in chickpea stover at control to $10 \mathrm{~kg} \mathrm{Zn} \mathrm{ha}^{-1}$.

The result indicated (Table 5) that total zinc uptake increased $43.1 \%$ and $41.6 \%, 36.2 \%$ and $29.7 \%$ and $18.5 \%$ and $24.9 \%$ with the application of sugarcane press mud, poultry manure and farm yard manure, respectively in case of rice and chickpea. On the other hand total zinc uptake in rice and chickpea increased with the application of $\mathrm{Zn}$. The magnitude of increase was $94.9 \%$ and $74.5 \%$ with application of $10 \mathrm{~kg} \mathrm{Zn} \mathrm{ha}^{-1}$. The uptake of nutrient is a function of yield and its concentration in crop as the residual effect of $\mathrm{Zn}$ there was increase in the yield as well as zinc concentration, ultimately the Zn uptake also increased. Zn uptake by rice crop increased from 214.9 $\mathrm{g} \mathrm{ha}^{-1}$ at $100 \%$ NPK to $315.2 \mathrm{~g} \mathrm{ha}^{-1}$ at $100 \% \mathrm{NPK}+$ farm yard manure, $382.6 \mathrm{~g} \mathrm{ha}^{-1}$ at $100 \% \mathrm{NPK}+\mathrm{Zn}$. Application of $30 \mathrm{~kg} \mathrm{ZnSO} 4 \mathrm{ha}^{-1}$ recorded the highest values of yield uptake of $\mathrm{Zn}, \mathrm{N}$ and $\mathrm{K}$ by rice plant (Ghatak et al., 2005).

Table 5. Effect of organic manures and $\mathrm{Zn}$ on Zinc and uptake $\left(\mathrm{g} \mathrm{ha}^{-1}\right)$ by rice-chickpea cropping sequence

\begin{tabular}{|c|c|c|c|c|c|c|}
\hline \multirow{3}{*}{ Treatments } & \multicolumn{6}{|c|}{ Zinc Uptake } \\
\hline & \multicolumn{3}{|c|}{ Rice } & \multicolumn{3}{|c|}{ Chickpea } \\
\hline & Grain & straw & Total & Grain & straw & Total \\
\hline \multicolumn{7}{|l|}{ Organic Manures } \\
\hline Control & 61.1 & 83.7 & 144.8 & 65.5 & 38.3 & 103.8 \\
\hline FYM & 76.8 & 104.1 & 180.9 & 81.2 & 51.1 & 134.6 \\
\hline $\mathrm{PM}$ & 84.0 & 113.2 & 197.3 & 76.4 & 46.6 & 123.0 \\
\hline SPM & 87.4 & 119.8 & 207.3 & 89.8 & 59.6 & 147.0 \\
\hline $\mathrm{CD}(\mathrm{P}=0.05)$ & 9.29 & 11.43 & 14.73 & 9.62 & 8.83 & 14.40 \\
\hline \multicolumn{7}{|l|}{ Zinc Fertilization } \\
\hline $\mathrm{Zn}_{0}$ & 51.2 & 70.0 & 121.3 & 56.7 & 33.7 & 90.3 \\
\hline $\mathrm{Zn}_{1}$ & 69.8 & 100.1 & 169.9 & 75.6 & 45.1 & 120.7 \\
\hline $\mathrm{Zn}_{2}$ & 86.3 & 116.5 & 202.7 & 86.1 & 53.5 & 139.6 \\
\hline $\mathrm{Zn}_{3}$ & 102.1 & 134.2 & 236.3 & 94.6 & 63.1 & 157.7 \\
\hline $\mathrm{CD}(\mathrm{P}=0.05)$ & 6.96 & 11.52 & 15.37 & 7.63 & 4.77 & 9.38 \\
\hline
\end{tabular}

Table 6. Correlation between $\mathrm{Zn}$ fractions with DTPA-Zn, and various $\mathrm{Zn}$ fractionations in rice- chickpea crops

\begin{tabular}{|c|c|c|c|c|c|c|c|c|c|c|c|c|c|c|}
\hline \multirow{2}{*}{ Zn Fractions } & \multicolumn{2}{|c|}{ DTPA- Zn } & \multicolumn{2}{|c|}{ Water Soluble } & \multicolumn{2}{|c|}{ Exchangeable } & \multicolumn{2}{|c|}{ Complexed } & \multicolumn{2}{|c|}{ Organic Bound } & \multicolumn{2}{|c|}{ Occluded } & \multicolumn{2}{|c|}{ Residual } \\
\hline & Rice & Chickpea & Rice & Chickpea & Rice & Chickpea & Rice & Chickpea & Rice & Chickpea & Rice & Chickpea & Rice & Chickpea \\
\hline Water Soluble & $0.90^{* *}$ & $0.79 * *$ & 1.00 & 1.00 & $0.77 * *$ & $0.74 * *$ & $0.91 * *$ & $0.92 * *$ & $0.70^{* *}$ & $0.49^{* *}$ & $0.43^{* *}$ & $0.45^{* *}$ & 0.28 & $0.41^{* *}$ \\
\hline Exchangeable & $0.76^{* *}$ & $0.77 * *$ & & & 1.00 & 1.00 & $0.78^{* *}$ & $0.75^{* *}$ & $0.67 * *$ & $0.55^{* *}$ & $0.41^{* *}$ & $0.38^{* *}$ & $0.32 *$ & $0.40^{* *}$ \\
\hline Complexed & $0.87^{* *}$ & $0.86^{* *}$ & & & & & 1.00 & 1.00 & $0.73 * *$ & $0.51 * *$ & $0.43 * *$ & $0.54 * *$ & 0.28 & $0.42 * *$ \\
\hline Organic Bound & $0.70^{* *}$ & $0.53 * *$ & & & & & & & 1.00 & 1.00 & $0.46^{* *}$ & $0.42 * *$ & 0.21 & 0.23 \\
\hline Occluded & $0.40^{* *}$ & $0.54^{* *}$ & & & & & & & & & 1.00 & 1.00 & 0.20 & $0.36^{*}$ \\
\hline Residual & $0.34 *$ & $0.43 * *$ & & & & & & & & & & & 1.00 & 1.00 \\
\hline
\end{tabular}

Note: * Significant at $\mathrm{P}=0.05 * *$ Significant at $\mathrm{P}=0.01$.

\subsection{Zinc Use Efficiency (ZUE)}

Zinc use efficiency (Figure 3) increased from 1. 34\% (control) to $1.69 \%$ with poultry manure and $1.77 \%$ with farm yard manure and sugarcane press mud application in case of rice. Whereas, as a residual effect, zinc use efficiency increased significantly from $0.77 \%$ at no organic manure (control) to farm yard 
manure $(1.23 \%)$ and sugarcane press mud $(1.18 \%)$ whereas, the application of poultry manure could not exerted any significant residual effect $(0.78 \%)$. On the other hand, Zinc use efficiency by rice and chickpea decreased significantly with the increasing levels of zinc from $1.97 \%$ and $1.21 \%$ at $2.5 \mathrm{~kg}$ $\mathrm{ha}^{-1} \mathrm{Zn}$ level to $1.25 \%$ and $0.74 \%$ at $10 \mathrm{~kg} \mathrm{ha}^{-1} \mathrm{Zn}$ level. Over all the zinc use efficiency was $1.64 \%$ in case of rice which decreased to $0.99 \%$ as a residual effect on chickpea. It was due to more uptake of $\mathrm{Zn}$ under FYM and SPM and lesser uptake in control, which resulted into more yield per unit of Zn uptake. On the other hand, Zinc use efficiency by rice and chickpea decreased significantly with the increasing levels of zinc. Our results are agreement with Rathod et al. (2012) they also reported that Zinc use efficiency due to $\mathrm{Zn}$-enrichment of organics at $2.5 \mathrm{~kg} \mathrm{ha}^{-1}$ improved over its, application as zinc sulphate in both wheat and maize crops.
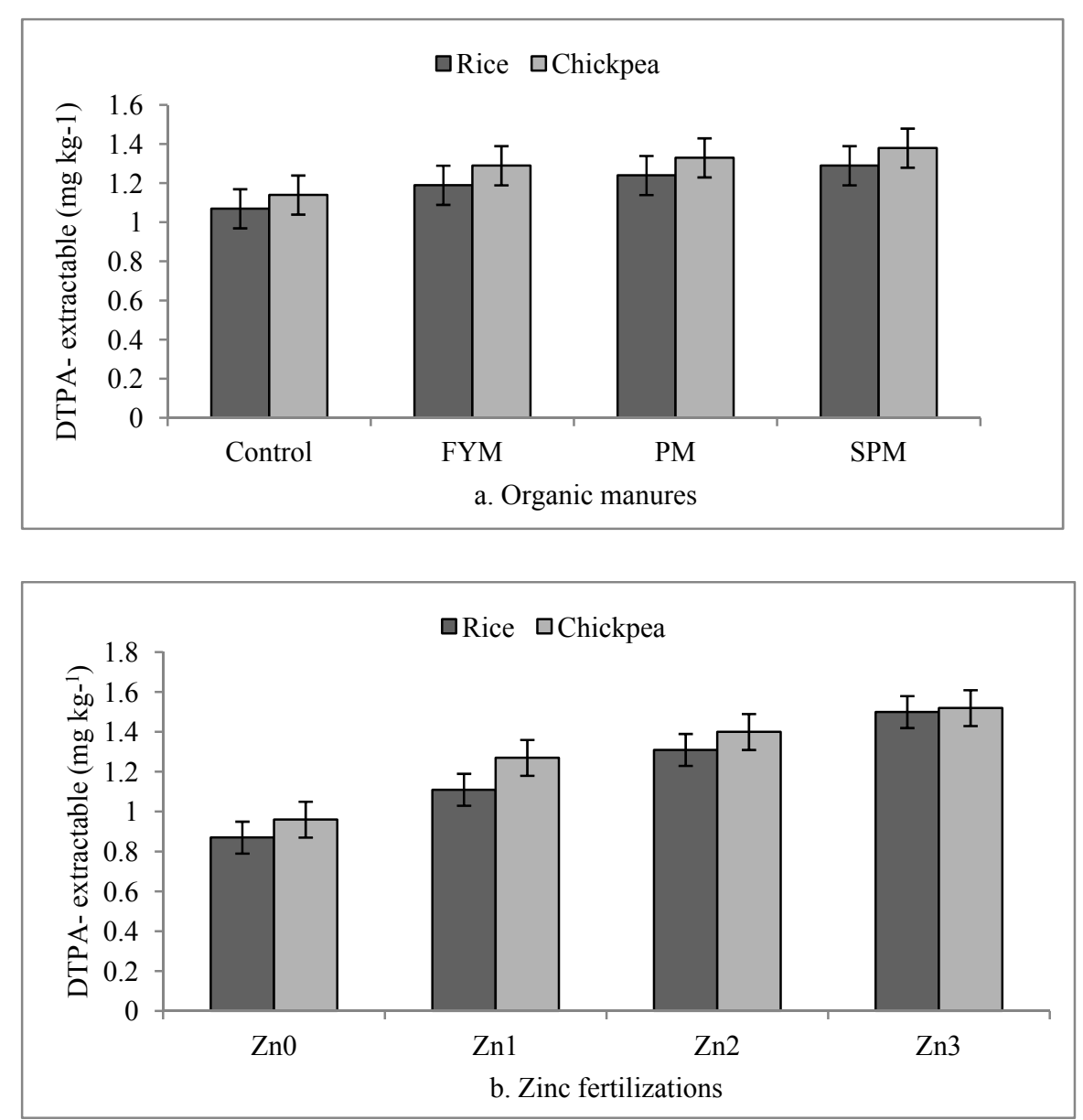

Figure 2. Effect of organic manures and zinc fertilization on extractable zinc in soil

Note: Vertical bar represent the significant level $(\mathrm{P}=0.05)$. 

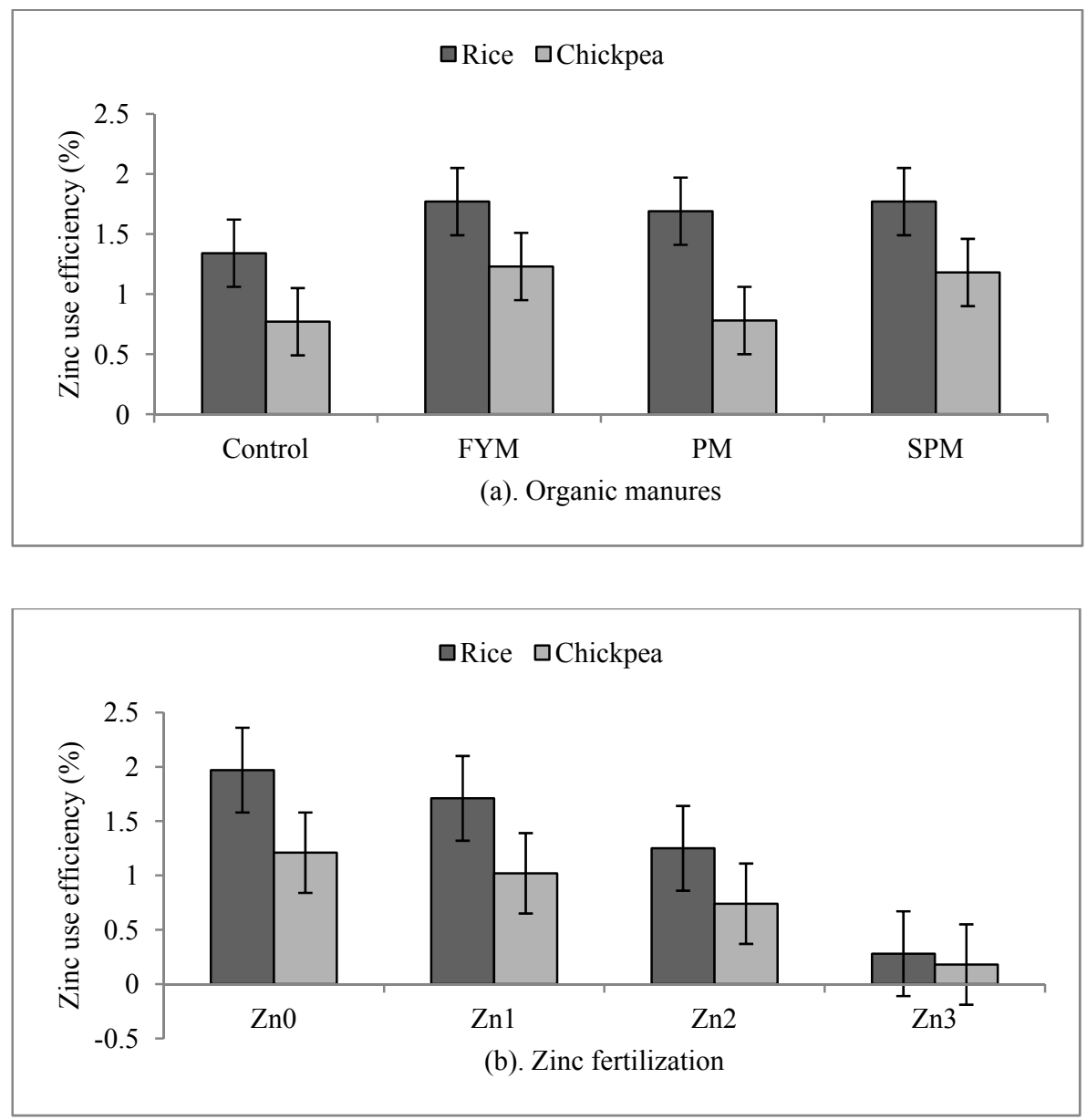

Figure 3. Effect of organic manures and zinc fertilization on zinc use efficiency of rice and chickpea

\subsection{Correlation Coefficient}

Correlation coefficient (r) indicated that water soluble form of zinc correlated positively and significantly in order of complexed $>$ Exchangeable $>$ organically bound and $>$ occluded $>$ residual. Exchangeable fraction significantly correlated with complexed $>$ organically bound $>$ and $>$ occluded. Complexed zinc was found positive relationship with organically bound, occluded and residual fraction while organically bound positively correlated with occluded zinc. The occluded and residual fractions also correlated significant with other fraction concluding that the $\mathrm{Zn}$ in soil remains in equilibrium in various pools and the direction of equilibrium, changes due to use or application of $\mathrm{Zn}$ from other sources. The more soluble fractions like water soluble, exchangeable and organic matter occluded ones are major contributors to available zinc. Our findings are conformity with Kumar et al. (2004). Similarly, Valdivia et al. (2002) also observed that the micronutrient content in maize positively correlated with the water-soluble plus exchangeable $\mathrm{Zn}$ as well as with the available $\mathrm{Zn}$ determined by the diethylene triamine penta acetic acid.

\section{Conclusions}

$\mathrm{Zn}$ fertilization in rice offers a practical and useful approach to improve bioavailable $\mathrm{Zn}$ in rice. According to current study $10 \mathrm{~kg} \mathrm{Zn} \mathrm{ha}{ }^{-1}$ with sugarcane press mud @ $5 \mathrm{t} \mathrm{ha}^{-1}$ are recommended as excellent $\mathrm{Zn}$ forms to ongoing agronomic biofortification. The available $\mathrm{Zn}$ status of soil increased significantly with the levels of $\mathrm{Zn}$ and amongst the organic manures in the order of sugarcane press mud $>$ poultry manure $>$ farm yard manure. Increasing levels of $\mathrm{Zn}$ contributed to the Zinc content in various fractions in soil. Organic manure also increased $\mathrm{Zn}$ content in various pools.

\section{References}

Akinrinde, E. A., Olubakin, O. A., Omotoso, S. O., \& Ahmed, A. A. (2006). Influence of zinc fertilizer, poultry manure and application levels on the performance of sweet corn. Agricultural Journal, 1, 96-103. 
Appauv, M., Manim, S., \& Savithri, P. (2001). Effect of organic manures (Poultry manure, goat manure and FYM) on the availability of $\mathrm{Zn}$ and other micronutrients. Madras Agricultural Journal, 84(7/9), 402-406.

Cakmak, I. (2008) Enrichment of cereal grains with zinc: Agronomic or genetic biofortification? Plant science, $302,1-17$.

Chesnin, L., \& Yien, C. H. (1951). Turbitymetric determination of available sulphur in soil. Soil Science Society of America Proceeding, 15, 149-151. http://dx.doi.org/10.2136/sssaj1951.036159950015000C0032x

Dobermann, A. (2005). Nitrogen Use Efficiency - State of the Art. Paper presented in IFA International Workshop on Enhanced-Efficiency of Fertilizers, Frankfurt, Germany, 28-30 June 2005, pp 1-18.

Dobermann, A., \& Fairhurst, T. (2000). Rice: Nutrient disorders and nutrient management (p. 191). Handbook series. Potash \& Phosphate Institute (PPI), Potash \& Phosphate Institute of Canada (PPIC) and International Rice Research Institute (IRRI).

Fang, Y., Wang, L., Xin, Z., Zhao, L., \& An, X. (2008). Effect of foliar application of zinc, selenium, and iron fertilizers on nutrients concentration and yield of rice grain in China. Journal of Agricultural Food Chemistry, 56, 2079-2084. http://dx.doi.org/10.1021/jf800150z

Ghatak, R., Jana, P. K., Sounda, G., Ghosh, R. K., \& Bandopadhyay, P. (2005). Responses of transplanted rice to $\mathrm{Zn}$ fertilization at farmers field on red and laterite soils of West Bengal. Journal Interacademicia, 9(2), 231-234.

Iyenger, B. R. V., \& Deb, D. L. (1977). Contribution of soil zinc fraction to plant uptake and rate of zinc applied to soil. Journal of Indian Society of Soil Science, 25, 426-432.

Jackson, M. L. (1965). Soil Chemical analysis. Prentice Hall Inc. Englewood Cliffs New Jersey.

Jalali, V. K., Gupta, J. P., Gupta, R. D., \& Khajuria, B. B. (1999). Chemical pools of zinc in intermediate zone of Jammu and response of maize of zinc. Applied Biological Research, 1(2), 167-169.

Kumar, S. P., Rattan, R. K., \& Singh, A. K. (2004). Chemical forms of zinc soils and their contribution to available pool. Journal of Indian Society of Soil Science, 52(4), 421-425.

Lindsay, W. L., \& Norvell, W. A. (1978). Development of ADTPA-Soil test for zinc, iron, manganese and cooper. Soil Science Society of American Journal, 42, 421-428. http://dx.doi.org/10.2136/sssaj1978.03615995004200030009x

Meena, M. C., Patel, K. P., \& Rathore, D. D. (2006). Effect of Zn and Fe enriched FYM on mustard yield and micronutrient availability in loamy sand soil (Topic Haplustept) of Anand. Micronutrient project (ICAR) Anand Agri University. Anand, Gujrat. Journal of Indian Society of Soil Science, 54(4), 495-499.

Mishra, P., Singh, R., Shrivastava, P. C., \& Ram, B. (2009). Effect of continuous cropping and fertilization on Zinc fractions and their contribution to plant uptake under rice-wheat system. Journal of Indian Society of Soil Science, 57(2), 167-171.

Muhr, G. R., Datta, N. P., Subaramany, H. S., Leley, V. K., \& Dunahue, R. L. (1963). Soil testing. India Asian press, New Delhi.

Olsen, S. R., \& Dean, A. L. (1954). Phosphorus, In Black (Ed. II), Methods of soil analysis part-2. American Society of Agronomy, Wisconsin, U.S.A. Monograph, 9, 1025-1404.

Patnaik, M. C., Sreenivasa, R. A., \& Bhupal, R. G. (2008). Effect of soil moisture regimes on Zinc availability in a Red Sandy Loam soil of Andhra Pradesh. Journal of Indian Society of Soil Science, 56(4), 452-453.

Rathod, D. D., Meena, M. C., \& Patel, K. P. (2012). Evaluation of different zinc-enriched organics as source of zinc under wheat- maize (fodder) cropping sequence on zinc- deficient Typic Haplustepts. Journal of Indian Society of Soil Science, 60(1), 50-56.

Rupa, T. R., Rao, C. S., Rao, A. S., Singh, M., \& Singh, M. (2003). Effect of farmyard manure and phosphorous on $\mathrm{Zn}$ transformation and phyto-availability in to Alfisols of India. Bioresource Technology, 87(3), 279-288. http://dx.doi.org/10.1016/S0960-8524(02)00235-3

Sharma, J. C., \& Chaudhary, S. K. (2007). Vertical Distribution of micronutrient cations in relation to soil characteristics in Lower Shiwaliks of Solan District in North-West Himalayas. Journal of Indian Society of Soil Science, 55(1), 40-44.

Shetty, Y. C., Vasuki, N., \& Rudreamurthy, H. V. (2001). Forms of zinc in tobacco of KLs region. Tobacco Research, 27(2), 109-115. 
Slaton, N. A., Gbur, E. E., Wilson, C. E., \& Norman, R. J. (2005). Rice response to granular zinc sources varying in water-soluble zinc. Soil Science Society of American Journal, 69, 443-452. http://dx.doi.org/10.2136/sssaj2005.0443

Smith, R. L., \& Shoukry, K. S. M. M. (1968). Change in the zinc distribution within three soils and zinc uptake by field beans caused by decomposing organic matter. Isotopes and radiation in soil organic matter. Proceeding of Symposium IAEA/FAO Vienna (pp. 397-410).

Sperotto, R. A., Ricachenevsky, K. F., Waldow Vinicius de Abreu, \& Janette, P. F. (2012). Iron biofortification in rice: It's a long way to the top. Plant Science, 190, 24-39. http://dx.doi.org/10.1016/j.plantsci.2012.03.004

Subbiah, B. V., \& Asija, G. L. (1956). A rapid procedure for the estimation of available nitrogen in soil. Current Science, 25, 259-260.

Veldivia, L. M. L., Fernandez, M. D., Obrador, A., \& Alvarez, J. M. (2002). Zinc transformation in acidic soil and zinc efficiency on maize by adding six organic zinc complexes. Journal of Agricultultural Food Chemistry, 50(6), 1455-1460. http://dx.doi.org/10.1021/jf010978v

Wu, C., Lu, L., Yang, X., Feng, Y., \& Wei, Y. (2010). Uptake, translocation, and remobilization of zinc absorbed at different growth stages by rice genotypes of different $\mathrm{Zn}$ densities. Journal of Agricultultural Food Chemistry, 58, 6767-6773. http://dx.doi.org/10.1021/jf100017e

\section{Copyrights}

Copyright for this article is retained by the author(s), with first publication rights granted to the journal.

This is an open-access article distributed under the terms and conditions of the Creative Commons Attribution license (http://creativecommons.org/licenses/by/3.0/). 